\title{
FACTORS INFLUENCING THE ACCESSIBILITY OF YAM PLANTING MATERIALS IN THE TECHIMAN DISTRICT OF GHANA
}

\author{
Ernest L. Okorley and Evans O. Addai
}

\author{
Department of Agric. Economics and Extension \\ University of Cape Coast, \\ Cape Cost, Ghana \\ E-mail: leokorley@yahoo.com
}

\begin{abstract}
Yam is a major economic crop that plays a significant role in food security and poverty alleviation in Ghana. Despite this role of yam in Ghana, farmers have incessant difficulty in accessing adequate planting materials for cultivation. In order to understand this problem, this research was conducted to determine the various factors that can influence the accessibility of yam planting materials to farmers in the Techiman District of the Brong Ahafo Region of Ghana. Quantitative and qualitative research techniques including semi-structured interviews and observations were employed for this study. The research identified six main factors as critical to accessing yam planting materials in the study area. These included the cultivar of yam that farmers want to grow, access to capital to purchase planting materials, and availability and cost of transportation to convey planting materials to store at farmer homes. The others were pests and diseases infestation of planting materials in storage, farmers' membership in co-operatives that assist members with acquisition of credit and/or planting materials, and the adoption of minisett and microsett techniques by farmers.
\end{abstract}

KEY DESCRIPTORS: Yam, Planting Materials, Seed Yam, Accessibility, Minisett and Microsett

\section{INTRODUCTION}

Yams belong to the plant species Dioscorea (D.) and the family Dioscoreaceae. Depending on the specie, the crop can be an annual or perennial climbing plant with edible underground tuber. More than ninety five percent of the world's yam is currently grown in Sub-Saharan Africa with the remainder in the West Indies and parts of South and Central America. There are 600 species of yam available (Coursey, 1967), but the important species that are cultivated in Ghana include D. rotundata (White Guinea yam), D. alata (Water yam), D. cayenensis (Yellow yam), D. dumentorum (Bitter yam) and D. trifida (Cushcush yam).

Yams contribute immensely to the socio-economic development of the Ghanaian economy (Doku, 1993). Ghana exports the largest quantity of yams (about 12,000 tonnes) annually (ITTA, 2008). The crop plays a significant role in food security and alleviating hunger not only in Ghana but many parts of Africa (Anon, 1998). In Ghana, yam is used mainly for human food consumption such as yam balls, mashed yam, yam chips, pounded yam and boiled yam. Notwithstanding its importance, yam production in Ghana has been on the decline despite the increasing demand the local consumption and for export. The production of the crop is confronted with a number of problems including high labour demand and high cost of cultural operations, unreliable sources of credit, pests and diseases, declining soil fertility, unpredictable weather conditions and the lack of yam planting material. (Tetteh \& Saakwa, 1994; IITA, 2008). Other factors are socio-cultural. For instance, in northern Ghana, the cultivation of yam is taboo to women. Women in their menstrual period are particularly disallowed from even visiting yam farms during specified times in the cultivation cycle.

In Ghana, the availability of yam planting material is a major constraint, thus, yam cultivation is limited by high costs of planting material (Tetteh \& Saakwa, 1994; IITA, 2008). It is believed that the 
acquisition of yam planting material in many instances constitutes as much as fifty percent of the total production cost (Degrass, 1993). Consequently, farmers reserve about thirty percent of their harvested tubers for next planting season, thereby reducing the total output of yam for consumption (Degrass, 1993). This problem of accessibility of yam planting material, and the desire to understand the underlying causes have formed the motivation behind this research. The purpose of the research was therefore to determine the factors that influence (promote or hinder) the accessibility of yam planting materials to farmers in the Techiman District. In the following sections, the research methodology is described, the results are presented and discussed, and conclusions and recommendations are drawn.

\section{METHODOLOGY}

The research was conducted between January and May 2008. A combination of quantitative and qualitative approaches based on semi-structured interviews and observations were used in the research. This approach was considered appropriate for an in-depth study of interrelated socialeconomic factors of farmers. The determining criteria for the selection of the participating district were its repute as a major yam producing area, availability commercial yam production and accessibility of the terrain. The Techiman District met the above criteria and was thus selected for the study. The District is situated in the northern part of the Brong-Ahafo Region and lies between longitude $1^{0} 49^{1}$ East $2^{0} 30^{1}$ West and latitude $8^{0} 00^{1}$ North and $7^{0} 35^{1}$ South. It is located in the transitional agro ecological zone of the Brong-Ahafo Region. The zone has an annual average rainfall of $1300 \mathrm{~mm}$ and a bimodal rain pattern with the major season starting from May to August, minor from September to mid December and a long dry season from the middle of December to April). The district covers an area of $669.7 \mathrm{~km}^{2}$ and has an annual temperature ranging from $20^{\circ}$ to $36^{\circ} \mathrm{C}$. The major occupation of the people in the study area is farming. Yam is the main crop cultivated in the area with most of the farmers cultivating between 1-3 hectares.

Participants for the research were selected from a broad area of the Techiman District. Four major yam growing communities in the District served as the target communities. They included Nsuta, Tanobuase, Ahansua, and Tuobodom. Ten key informants were selected from each of the communities on the basis that they were commercial yam farmers and willing to participate in the research. In total, forty (40) yam farmers were selected as participants of the research. Multiple sources of data collection were used - mainly interviews based on semi-structured questionnaires and observations. Quantitative data were collected and analysed with descriptive statistics including frequencies and percentages. The use of statistics here was not primarily for the purpose of generalization of the findings to yam farmers, but to show the different views of the key informants, and to emphasise the importance of some factors in understanding what influence the accessibility of yam planting materials among yam farmers in the study area. Qualitative data analysis approach was used to analyse the qualitative data. This involved coding data and searching for relationships to establish factors that promote or hinder the accessibility of yam planting materials in the study area.

\section{RESULTS AND DISCUSSION}

\section{Background Information}

Out of the forty yam farmers that participated in the research, thirty three (82.5\%) were males and the rest females. In the study areas it was observed that, yam production was predominantly done by males. The major reasons attributed to this gender role was the laborious nature of the cultural practices (raising mounds, staking etc.) and also the need for large land area for yam cultivation men have more access to land than women in the Techiman District. Most of the farmers (60\%) had no formal education and cultivated between $2-4$ hectares of land - characteristics common to most small scale farmers in Ghana. On the average, each yam farmer in the research cultivates about 
2.3 hectares of land area. The issue of communal ownership of land contributed to this small scale production since individuals under this system have access to small portions of land allocated to them by the family/community head. In addition, insufficient capital and high cost of labour were contributing factors to the small scale production of yam in the study area. The informants complained about insufficient resources (capital, labour, and land) to expand their farms. Yam is the staple food crop of the area and as such, the farmers who participated in the research have had long years of experience in yam cultivation (average of 19.2 years).

\section{The Predominant Yam Cultivars Grown by the Farmers}

To understand the factors that can influence the accessibility of yam planting material to farmers, it is important to know the types of yam grown by farmers in the study area. It was observed that the farmers in the generally grow more than one cultivar of yam on their farm. When they were asked to give the predominant yam cultivar they grow, the farmers identified five main cultivars (See Table 1 below). The results showed that Pona ( $D$. rotundata) was the most popular yam cultivar grown in the Techiman District. It was followed by Dente (D. rotundata), Afasie (D. alata), Dedee ( $D$. cayenensis) and Dobene (D. cayenensis) in a decreasing order of popularity. The key informants indicated that they prefer the pona because it matures early, has a good taste, a good market, and yields better compared to other cultivars.

Table 1: The predominant yam cultivar grown by the farmers

\begin{tabular}{llll}
\hline Local Cultivar & Specie & Frequency & Percentage \\
\hline Pona & Dioscorea rotundata & 20 & 50 \\
Dente & Dioscorea rotundata & 8 & 20 \\
Afasie & Dioscorea alata & 6 & 15 \\
Dedee & Dioscorea cayenensis & 4 & 10 \\
Dobene & Dioscorea cayenensis & 2 & 5 \\
\hline Total & & 40 & 100 \\
\hline
\end{tabular}

Source: Field data, 2008

\section{The Type and Source of Yam Planning Materials Used by the Farmers}

The most popular planting material used among farmers in the study area is yam setts. A simple analysis of the farmers in the research showed that 70 percent of them were using yam setts as their main planting material. The rest of the farmers were using tuber cuttings, which was expected, especially for those who were cultivating Afasie. Degrass (1993) had pointed out that the best means of cultivating some varieties of yam including Afasie is by tuber cuttings. Interestingly, it was observed that most of the farmers acquired their planting materials from their own farms, except a few who claimed they bought some more from the market. Farmers in the area generally practice "milking", a traditional method of seed yam production, especially for D rotundata. This is the practice of removing developing tubers (mother tubers) from growing yam plants to give farmers double harvest in a year. The first harvest tubers are consumed (or sold) by the household whilst those of the second harvest are picked three months later and reserved as seed yam for planting. This finding is in agreement with Degrass' (1993) assertion that most yam farmers store considerable amount of their total output as planting materials for the next planting season. According to the key 
informants, they prefer planting material from their own farms because it is expensive to buy from the market.

\section{Factors that Constrained Acquisition of Yam Planting Materials by the Farmers}

The major constraints found to have hindered the farmers' ability to obtain yam planting materials for cultivation were inadequate capital, high transportation cost and pest infestation. Of the forty yam farmers that were interviewed, 95 percent of them indicated that they lack the capital to either expand their farms or buy yam setts from the market. Another 37.5 percent and 32.5 percent of the farmers highlighted the issue of high transportation cost and pest infestation respectively as key constraints to yam planting material accessibility in the Techiman District. It was observed that the problem of transportation in the area was mainly due to the poor feeder roads linking the villages and the farms where the planting materials are. Most of these feeder roads need constant maintenance because they are not tarred and become muddy and impassable to motorists, especially during the rainy seasons. Consequently, it is difficult to transport the bulky yam planting materials either by head-load or vehicles. Furthermore, the vehicular transport conditions vary substantially from the very low to infrequent services to the villages, besides, the fare are usually exorbitant when farmers had to make private arrangements.

The key informants pointed out that pest and disease infestation of yam setts in storage are major problems to yam farmers in the study area. Most yam tubers kept to be used as planting material get invaded by pests such as yam beetle (Heteroligus meles) and rodents (mice and rats) and make them unwholesome for use as planting materials. In the light of these problems, the farmers rely mostly on the available setts they are able to transport by head-load from their own farms to store at home for the next planting season. See Table 2 below.

Table 2: Constraints in acquiring yam planting materials

\begin{tabular}{lll}
\hline Problem & Frequency* & Percentage \\
\hline Inadequate capital & 38 & 95.0 \\
Transportation cost & 18 & 45.0 \\
Pest infestation & 13 & 32.5 \\
\hline
\end{tabular}

* Multiple responses

Source: Field data, 2008

\section{Factors that Facilitated Acquisition of Yam Planting Materials by the Farmers}

When the key informants were asked to indicate one most important factor that had facilitated their ability to acquire yam planting materials for cultivation, two key factors were revealed, (1) being a member of a co-operative and (2) the use of improved propagation methods (See Table 3 below). Twenty seven of the informants (67.5\%) explained that by joining yam farmers' co-operatives in the district, they are able to get more yam planting materials. The farmers indicated that the cooperatives provided them with good information on new propagation methods and access to loans to purchase planting materials from the market. In some cases, the co-operatives provided planting materials for members at affordable prices with flexible mode of payment. For those farmers (32.5\%), who highlighted the importance of the minisetts and microsetts techniques, they explained that the techniques enabled them to obtain larger quantities of planting materials per tuber of yam. The minisett technique involves the planting of pre-germinated pieces of yam ranging from 20 to 40 grams directly into the field for seed production, whereas in the microsett technique, the pieces are 
smaller (3.5 gram), and usually treated with phytohormones before planting (World Bank, 1987). The farmers used the two techniques with the assistance from extension agents from the Ministry of Food and Agriculture in the District.

Table 3: Factors that facilitate the acquisition of yam planting materials

\begin{tabular}{lll}
\hline Measures & Frequency & Percentage \\
\hline Being a member of a co-operative & 27 & 67.5 \\
Use of minisetts and microsetts techniques & 13 & 32.5 \\
\hline Total & 40 & 100 \\
\hline
\end{tabular}

Source: Field data, 2008

\section{CONCLUSIONS}

Based on this study, it can be concluded that farmers grow five main local cultivars of yam in the Techiman District of the Brong-Ahafo Region of Ghana. These include Pona, Dente, Afasie, Dedee and Dobene. The most dominant among them is the cultivar Pona. The predominant planting material used in the study area is yam setts and is mostly obtained from farmers' own farms. From the finding, it can be concluded that six main factors influence farmer accessibility of yam planting materials in the Techiman District. These include:

- The cultivar of yam: The availability of planting material to farmers depends on the cultivar of yam one wants to farm. Those farmers involved in the cultivation of Afasie have very little problems with planting materials as it is easy for them to use tuber cuttings to obtain the quantities of planting materials they need for cultivation. Many of the problems identified as limiting farmers accessibility to planting material in this research relates more to yam sett acquisition especially for Pona and Dente, the predominant yam cultivars grown in the area.

- Availability of credit to farmers: Farmers who have access to affordable credit are in a position to invest into buying yam setts from the market for planting.

- Accessibility and cost of transportation: Where farms are accessible and the cost of transportation are lower, farmers who rely on planting materials from their own farms can convey large amount of planting materials to store at home to protect them from unfavourable weather conditions and pests.

- Pests and diseases infestation: Pests and diseases infestation tend to affect the accessibility of yam planting materials in the study area. Where yam planting materials are infested with pests and diseases there is loss in quantity and quality of the planting materials.

- Joining serviceable co-operatives: Co-operatives can facilitate the acquisition of yam planting material by providing their members with information on new propagation techniques and access to credit for buying more planting materials from the market.

- Adoption of improved propagation methods: The adoption of minisetts and microsetts techniques has proven to improve the accessibility of yam planting materials by quantity and quality to farmers.

\section{RECOMMENDATIONS}

Based on the above conclusions, it is recommended that: 
- The Crop Research Institute in collaboration with Ministry of Food and Agriculture (MoFA) need to research into and promote the utilisation of other equally important yam cultivars (e.g. Afasie) that are easy to propagate.

- MoFA and other development organizations (e.g. NGOs) need to assist farmers to organise into co-operative groups to combine their efforts to address the problems of transportation, and to attract credit from commercial banks to buy yam setts.

- MoFA would need to intensify their extension services on the control of storage pests and diseases of yam in the districts and other yam growing areas in Ghana.

- MoFA and other development organizations (NGOs) would have to intensify their extension work to promote the minisett and microsett technologies to farmers in the Techiman District and other yam growing areas in Ghana.

\section{REFERENCES}

Anon, Y. K. (1998). Five Year Agricultural Development Programme 1998-2002. Berekum: MoFA.

Coursey D. G. (1967). Yams, an account of the nature, origins, cultivation and utilisation of the useful members of the Dioscoreaceae. Tropical Agriculture Series, Tropical Products Institute, Longmans, London

Degrass, L. (1993). The Yam. A Tropical Root Crop. ( $3^{\text {rd }}$ ed). London: Macmillan Press

Doku, V.K.(1993). Enhancing yam production and supply of quality yams in Ghana. Accra: University of Ghana Press, Legon.

International Institute of Tropical Agriculture (2007). Yam. Retrieved July 10, 2008, from IITA Web site: http://www.iita.org/cms/details/yam projectdetails.aspx?zoneid $=63 \&$ articleid $=268$.

Tetteh, J.P. \& Saakwa, C. (1994). Prospects and Constraints to Yam Production in Ghana. Acta Hort. (ISHS) 380:355-359.

World Bank (1987) West Africa Agricultural Research Review. (985-86). World Bank: World Bank Western Africa Projects Department, Washington, D.C. 